\title{
Light-Enhanced Microbial Organic Carbon Yield
}

\author{
John R. Casey*, Sara Ferrón and David M. Karl \\ Center for Microbial Oceanography, School of Ocean and Earth Science and Technology, University of Hawaii at Manoa, \\ Honolulu, HI, United States
}

Molecular evidence for proteorhodopsin- and bacteriochlorophyll-based photoheterotrophy is widespread in oligotrophic marine microbial community metagenomes, and has been implicated in light-enhanced growth rates, substrate uptake rates, and anapleurotic carbon fixation, thus complicating the web of interactions within the 'microbial loop.' We quantified photoheterotrophic metabolism of the oxidized organic acid glycolate, a fast-turnover and exclusively phytoplankton-derived substrate at an oligotrophic site in the subtropical North Pacific Ocean. As expected, concentration-dependent changes in uptake rates were observed over the diel cycle, with maxima occurring at midday. Although no light-enhanced substrate uptake rates were observed, samples exposed to light altered the balance between assimilation and respiration, resulting in an approximately four-fold increase in glycolate-specific assimilation efficiency. Energy demand for such a metabolic adjustment was linearly

\section{OPEN ACCESS}

Edited by:

Matthew J. Church, University of Montana, United States

Reviewed by:

David L. Kirchman, University of Delaware, United States

Yao Zhang,

Xiamen University, China

*Correspondence: John R. Casey jrcasey@hawaii.edu

Specialty section: This article was submitted to

Aquatic Microbiology, a section of the journal

Frontiers in Microbiology

Received: 24 August 2017 Accepted: 20 October 2017 Published: 16 November 2017

Citation:

Casey JR, Ferrón S and Karl DM (2017) Light-Enhanced Microbial Organic Carbon Yield.

Front. Microbiol. 8:2157. doi: 10.3389/fmicb.2017.02157 related to light, consistent with photoheterotrophy.

Keywords: photoheterotrophy, glycolate, substrate assimilation efficiency, photorespiration, diel cycles of microbial metabolism

\section{INTRODUCTION}

The web of microbially mediated transformations of carbon and energy in the oceans is intricate and dynamic. The conduit through which a great majority of oceanic respiration is channeled is the dissolved organic matter (DOM) reservoir. DOM is composed of thousands of unique molecules in widely varying concentrations (Mopper et al., 2007), and the spectrum of turnover spans from minutes (Fuhrman and Ferguson, 1986) to millennia (Ziolkowski and Druffel, 2010; Zigah et al., 2017). Among other physicochemical attributes, the thermodynamic properties of organic substrates governs their turnover, with high enthalpy substrates supporting sub-optimal microbial growth rates and therefore turning over more slowly than low enthalpy substrates (Casey et al., 2015). However, since the discovery of two unique light-harvesting systems widespread in marine bacteria and archaea, aerobic anoxygenic phototrophy (AAP; Shiba et al., 1979) and proteorhodopsin (PR) phototrophy (PRP; Béjà et al., 2000), the traditional view of a primary producer-DOM-secondary producer microbial loop (Azam et al., 1983) should be revised (Karl, 2014). Collectively, PR and aerobic anoxygenic phototrophic bacteria and archaea comprise most of the total heterotrophic microbial community in oligotrophic marine ecosystems (Rusch et al., 2007), and PRs have been found in diverse bacterial phyla (McCarren and DeLong, 2007), including the numerically dominant alphaproteobacterium SAR11 and marine archaea (Frigaard et al., 2006). While nutrient and ion transport have been associated with rhodopsins (Chan et al., 1981; Dimroth, 1990; Feng et al., 2013; Inoue et al., 2013; Kwon et al., 2013; Yoshizawa et al., 2014), both PR and the bacteriochlorophyll $(\mathrm{BChl})$ complex are capable of generating a proton motive force 
(pmf) to supplement the ATP demands of biosynthetic and maintenance functions. The PR pmf generated has been shown in monoclonal cultures to markedly stimulate growth rates (GómezConsarnau et al., 2007; Kimura et al., 2011; Palovaara et al., 2014), anapleurotic carbon fixation rates (Palovaara et al., 2014), substrate uptake rates (Alonso-Saez et al., 2006; Michelou et al., 2007; Mary et al., 2008), and to resuscitate carbon-starved cells (Gómez-Consarnau et al., 2010; Steindler et al., 2011). Whether the high abundance and diversity of AAP and PRP in the marine environment indicates a physiological cost-benefit solution to energy limitation of heterotrophic microbial growth on low-yield, thermodynamically efficient substrates remains unclear.

The PRP and AAP pmf may provide microbes with a reliable energy source to supplement, or perhaps to partly relieve oxidative phosphorylation demands (Johnston et al., 2005). Indeed, Koblížek et al. (2010) measured a 70\% reduction in respiration rates of an AAP Roseobacter isolate when grown on glutamate as a sole carbon source in the presence of light. Accordingly, the 'shaft work' provided to facultative photoorganoheterotrophs by photochemical energy transduction should decouple substrate chemical energy potential from the anabolic yields of obligate chemoorganoheterotrophs (von Stockar et al., 2006). We hypothesized that light repression of photoorganoheterotrophic respiration improves substratespecific growth yields within natural microbial assemblages, especially for substrates more oxidized than their anabolic endproducts.

Light-enhanced nucleic acid and amino acid assimilation rates have been reported in whole communities (Church et al., 2004, 2006) and within flow cytometry sorted populations of Prochlorococcus, Synechococcus, and small, low nucleic acid bacterioplankton, including SAR11 (Michelou et al., 2007; Mary et al., 2008; Gómez-Pereira et al., 2012). However, sorted populations have not been directly linked to their respective respiration rates, and thus evidence for light-enhanced bacterial growth efficiency has necessarily been inferred from bulk oxygen consumption (Cottrell et al., 2008). A suitable substrate to evaluate light-enhanced heterotrophic growth yield is the hydroxy acid glycolate. Glycolate has long been recognized to be an important light-dependent excretory product of phytoplankton (Tolbert and Zill, 1957; Nalewajko et al., 1963), and featured at the center of a lively debate regarding its extracellular production (Sharp, 1977; Mague et al., 1980; Fogg, 1983; Bjørnsen, 1988) and consumption by heterotrophic bacteria (Wright and Shah, 1977). Glycolate is secreted as a result of photorespiration from photoautotrophic microbes like high-light adapted Prochlorococcus strains (Bertilsson et al., 2005), some of which lack a complete salvage pathway (Casey et al., 2016). Since photorespiration is likely the sole extracellular source of glycolate, and since glycolate permease transporters and glycolate oxidases and dehydrogenases are present in SAR11, glycolate represents a direct transfer of oxidized, newly fixed photosynthate to support heterotrophic carbon and energy demands. In this study, radiorespirometry experiments were conducted to determine the concentrationdependent kinetics of glycolate uptake, the diel cycle of glycolate uptake, and the effect of light within that cycle and as a function of depth within the euphotic zone (5-100 m).

\section{MATERIALS AND METHODS}

\section{Station Locations and Sample Collection}

Samples were collected on two separate expeditions (Cruise 1 - September 2013 at $22^{\circ} 75^{\prime} \mathrm{N}, 158^{\circ} 00^{\prime} \mathrm{W}$ and Cruise 2 - July-August 2015 at $24^{\circ} 25^{\prime} \mathrm{N}, 156^{\circ} 45^{\prime} \mathrm{W}$ ) in the North Pacific Subtropical Gyre north of the island of O'ahu. The kinetics experiment was carried out during Cruise 1. Cruise 2 followed a semi-Lagrangian track near the center of an anticyclonic mode-water eddy feature, facilitated by maintaining ship's position with World Ocean Circulation Experiment Surface Velocity Profile drifters with $15 \mathrm{~m}$-depth drogues. Sampling for glycolate tracer incubation time-series was conducted at $4 \mathrm{~h}$ intervals, uninterrupted over the course of 2 days. Additionally, a depth profile of glycolate uptake rates was conducted using a surface-tethered array, designed to accommodate sample bottles suspended at 5, 25, 50, 75, and $100 \mathrm{~m}$, which were deployed from dawn to dusk on the last day of the time-series experiments. Water samples were collected using polyvinyl chloride Niskin ${ }^{\circledR}$ bottles mounted on a rosette equipped with dual conductivity, temperature, pressure, and oxygen sensors, a transmissometer, and a triplet fluorometer (SBE 911plus, Sea-Bird Electronics, Inc.). Photosynthetically active radiation (PAR; 400-700 $\mathrm{nm}$ wavelength band) are measured both at the surface in time-series experiments by shipboard quantum cosine sensor (LI-190R; LI-COR Inc.) with data logger (LI-1000; LI-COR Inc.), and also in depth profiles $(0-190 \mathrm{~m})$ by a free-falling profiling hyperspectral radiometer (HyperPro, Satlantic LP.). Incubation time-integrated PAR was calculated by scaling shipboard PAR to incubator transmittance (50\%).

\section{Community Stocks, Production, and Respiration Data}

Alongside glycolate incubations, samples were collected for chlorophyll a (Chl a), primary production (PP), and microbial community respiration (MCR). Chl a and PP measurements were conducted according to Hawaii Ocean Time-series standard protocols (Karl and Dore, 2001 ${ }^{1}$ ). Briefly, for Chl a, $125 \mathrm{ml}$ samples were pressure filtered onto $25 \mathrm{~mm}$ glass fiber filters (Whatman GF/F) and stored in acetone at $-20^{\circ} \mathrm{C}$ until analyzed fluorometrically. For PP, $500 \mathrm{ml}$ samples were collected in triplicate at different depths and incubated in situ on a surfacetethered array deployed before sunrise and recovered after sunset. Prior to deployment, bottles were spiked with $\mathrm{H}^{14} \mathrm{CO}_{3}{ }^{-}$to yield a final radioactivity of approximately $2 \mathrm{MBq} \mathrm{L}^{-1}$. After a $14 \mathrm{~h}$ incubation, samples were filtered onto $\mathrm{GF} / \mathrm{F}$ filters, acidified in glass scintillation vials with $1 \mathrm{ml} 2 \mathrm{M}$ hydrochloric acid and allowed to vent for $24 \mathrm{~h}$ prior to the addition of $10 \mathrm{ml}$ Ultima Gold LLN cocktail and liquid scintillation counting. Similarly, samples for gross oxygen production (GOP)

${ }^{1}$ http://hahana.soest.hawaii.edu/hot/methods/results.html 
and MCR were collected in triplicate in $125 \mathrm{ml}$ Pyrex glass bottles, spiked with $\mathrm{H}_{2}{ }^{18} \mathrm{O}$ (Medical Isotopes, $97.2 \%{ }^{18} \mathrm{O}$ ) to a final $\delta^{18} \mathrm{O}\left(\mathrm{H}_{2} \mathrm{O}\right)$ of approximately $2300 \%$, and incubated in situ along with the PP array. After recovery, biological activity was stopped by adding $100 \mu \mathrm{L}$ of saturated mercuric chloride solution. In addition, triplicate time-zero samples were collected at each depth and poisoned at the beginning of the deployment. Mass-to-charge $(\mathrm{m} / \mathrm{z})$ ratios of $32\left({ }^{16} \mathrm{O}^{16} \mathrm{O}\right)$, $34\left({ }^{18} \mathrm{O}^{16} \mathrm{O}\right)$, and $40(\mathrm{Ar})$ were quantified using membrane inlet mass spectrometry (MIMS) following Ferrón et al. (2016). The system consists of a water inlet, described in detail by Kana et al. (1994), and an analyzer, consisting of a HiQuad ${ }^{\mathrm{TM}}$ quadrupole mass spectrometer (QMG 700) with a cross-beam ion source, a Faraday collector, and a $90^{\circ}$ off-axis secondary electron multiplier (SEM), connected to a Pfeiffer Vacuum HiCube 80 Eco turbo pumping station. MCR was determined as the difference between GOP and the net $\mathrm{O}_{2}$ change during the incubation (Ferrón et al., 2016).

\section{Glycolate Kinetics and Uptake Experiments}

Incubations for glycolate kinetics and diel uptake rates were conducted in semi-transparent acrylic (shaded to approximately match the $15 \mathrm{~m}$ depth of sampling) or darkened deckboard incubators flushed with circulating surface seawater to maintain in situ temperatures. Incubator bath temperatures were monitored by HOBO Pendant ${ }^{\circledR}$ Data Loggers (Onset Computer Corp.). We refer to samples incubated at simulated light levels of $15 \mathrm{~m}$ depth as 'unshaded', and samples incubated in dark conditions as 'shaded,' so as not to be confused with nighttime. Accordingly, 'light' and 'dark' refer to daytime and nighttime.

Experimental procedures for glycolate incubations were described in Casey et al. (2015). Briefly, $60 \mathrm{ml}$ samples were spiked with $\left[\mathrm{U}_{-}{ }^{14} \mathrm{C}\right]$-glycolic acid calcium salt $\left({ }^{14} \mathrm{C}\right.$-glycolate herein; American Radiolabeled Chemicals, Inc.) at a specific radioactivity of $1.48 \mathrm{TBq} \mathrm{mol}^{-1}$. For the kinetics experiment, nine spike concentrations were added, ranging from 1 to $348 \mathrm{nM}$, spaced logarithmically. For all other incubations, spike concentrations were $10 \mathrm{nM}$. Uptake time series samples were collected at $4 \mathrm{~h}$ intervals for 2 days, Samples were incubated for $4.7 \pm 0.4 \mathrm{~h}$. All samples were incubated in triplicate and a $500 \mu \mathrm{L}$ total activity aliquot was collected from each sample prior to incubation. For glycolate assimilation rates $\left(v_{A}\right)$, samples were filtered under gentle vacuum $(<70 \mathrm{mBar})$ directly after incubation onto $25 \mathrm{~mm}$ glass fiber filters (nominal pore size $0.3 \mu \mathrm{m}$; GF75, Sterlitech Corp.) and rinsed with three volumes of $20 \mathrm{ml} 0.2 \mu \mathrm{m}$ filtered seawater. Filters were transferred to $20 \mathrm{ml}$ glass scintillation vials and submerged in $10 \mathrm{ml}$ scintillation cocktail (Ultima Gold LLT, Perkin Elmer). To account for ${ }^{14} \mathrm{C}$-glycolate adsorbed to cells or glass fiber filters, a "killed-control" replicate sample poisoned with $2 \%$ final concentration paraformaldehyde was included prior to each incubation. Killed-controls were incubated alongside live samples and processed identically. Assimilation depth profiles were conducted alongside PP and MCR in situ arrays.
For glycolate respiration rates $\left(v_{R}\right), 125 \mathrm{ml}$ glass serum bottles were fitted with rubber sleeve stoppers pierced with center well cups containing a dry piece of fluted cellulose paper (Whatman \#2) positioned in the headspace. Respiration incubations were terminated by first soaking the filter paper with $150 \mu \mathrm{L}$ phenethylamine and then acidifying the sample with $4 \mathrm{ml} 4.5 \mathrm{~N}$ sulfuric acid through the gas-tight stopper. The acidified sample was allowed to react for at least $48 \mathrm{~h}$ before removing the stoppers. This procedure is designed to completely capture the respired ${ }^{14} \mathrm{CO}_{2}$. Center well cups were transferred to $20 \mathrm{ml}$ glass scintillation vials and submerged in $10 \mathrm{ml}$ scintillation cocktail. A complete radiochemical mass balance $(100 \pm 4 \%)$ was achieved in the kinetics experiment, and recovery was independent of substrate concentration.

Glycolate uptake rates were calculated as the sum of assimilation and respiration rates. Glycolate-specific energy transduction was calculated as the difference in glycolate respiratory energy yield $\left(Y_{E}\right)$ in shaded and unshaded samples incubated during daylight hours $\left(Y_{E \text {, Shaded }}-Y_{E \text {, Unshaded }}\right)$. Glycolate energy yield was calculated as the product of the respiration rate and the standard molar enthalpy of combustion $\left(Y_{\mathrm{E}}=v_{\mathrm{R}} \times \Delta \mathrm{H}_{\mathrm{C}}^{\circ}\right)$ of glycolate. Throughout, two-tailed $t$-tests were used to determine significant differences between treatments, and correlation coefficients were determined from model I or model II least-squares regressions, as appropriate for the experimental conditions (Laws, 1997).

\section{RESULTS}

\section{Glycolate Kinetics Experiment}

Two distinct kinetics profiles were observed for dark glycolate assimilation and respiration (Figure 1). Assimilation followed a

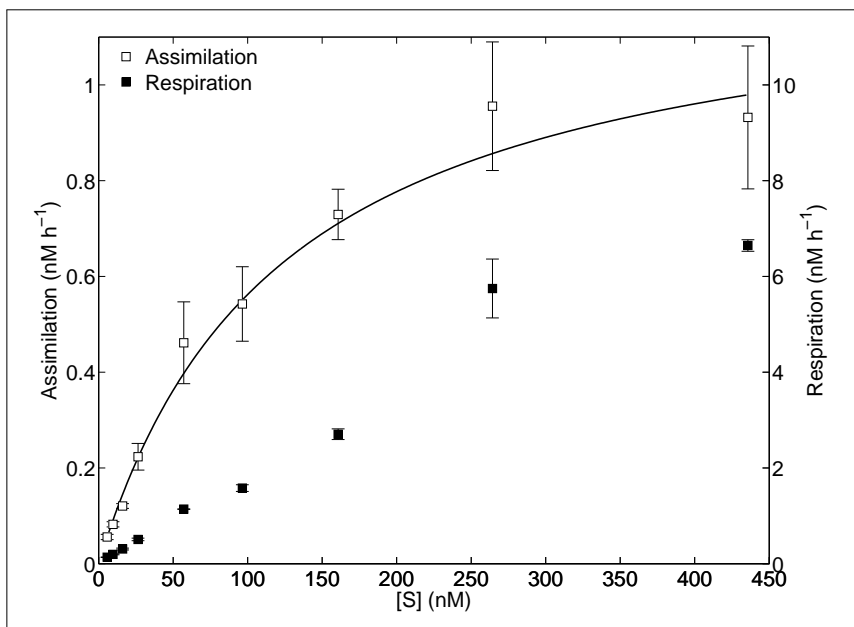

FIGURE 1 | Kinetics experiment. Glycolate assimilation and respiration as a function of added substrate. Error bars represent one standard deviation of the mean rates of three replicates at each concentration. Michaelis-Menten non-linear least-squares regression line is shown (solid line) for assimilation data. 
monophasic Michaelis-Menten function with a resulting halfsaturation concentration $\left(K_{\mathrm{m}, \mathrm{A}}\right)$ of $118 \mathrm{nM}$ and a maximum velocity $\left(V_{\max , \mathrm{A}}\right)$ of $1.2 \mathrm{nM} \mathrm{h}^{-1}$. Glycolate respiration did not appear to completely saturate over the concentration range tested, therefore $K_{\mathrm{m}, \mathrm{R}}$ and $V_{\max , \mathrm{R}}$ could not be determined. The resulting uptake parameters $K_{\mathrm{m}, \mathrm{U}}$ and $V_{\max , \mathrm{U}}$ were calculated to be 195 and $8.9 \mathrm{nM} \mathrm{h}^{-1}$, respectively. Glycolate-specific assimilation efficiency $\left(100 * \mathcal{V}_{\mathrm{A}} / \mathcal{V}_{\mathrm{A}}+\mathcal{V}_{\mathrm{R}}\right)$ varied as a logistic function of substrate concentration added (S), with highest efficiencies $(29.3 \pm 0.9 \%)$ corresponding to $S<57 \mathrm{nM}$. At saturating substrate concentrations, the assimilation efficiency approached $12 \%$. The glycolate turnover rate was $0.63 \mathrm{~d}^{-1}$, a half-life of $26 \mathrm{~h}$.

\section{Glycolate Diel Time-Series Experiment}

Glycolate uptake rates varied by roughly three-fold (280 $\pm 70 \%)$ over the diel cycle, in phase with the solar cycle, and no difference between shaded and unshaded uptake rates was observed (two-sample $t$-test with unequal variance; $p=0.39$; Figure 2). Glycolate assimilation rates also followed a diel cycle $(310 \pm 110 \%)$, but with maximal rates occurring in unshaded samples in the morning or early afternoon (600-1400 h, local time). Assimilation rates in shaded samples were $35 \pm 7 \%$ lower than in unshaded samples $(p=0.007)$ during daylight hours, and were similar to nighttime samples $(p=0.42)$. In contrast, glycolate respiration rates in shaded samples were $120 \pm 14 \%$ higher than unshaded samples $(p<0.001)$ during daylight
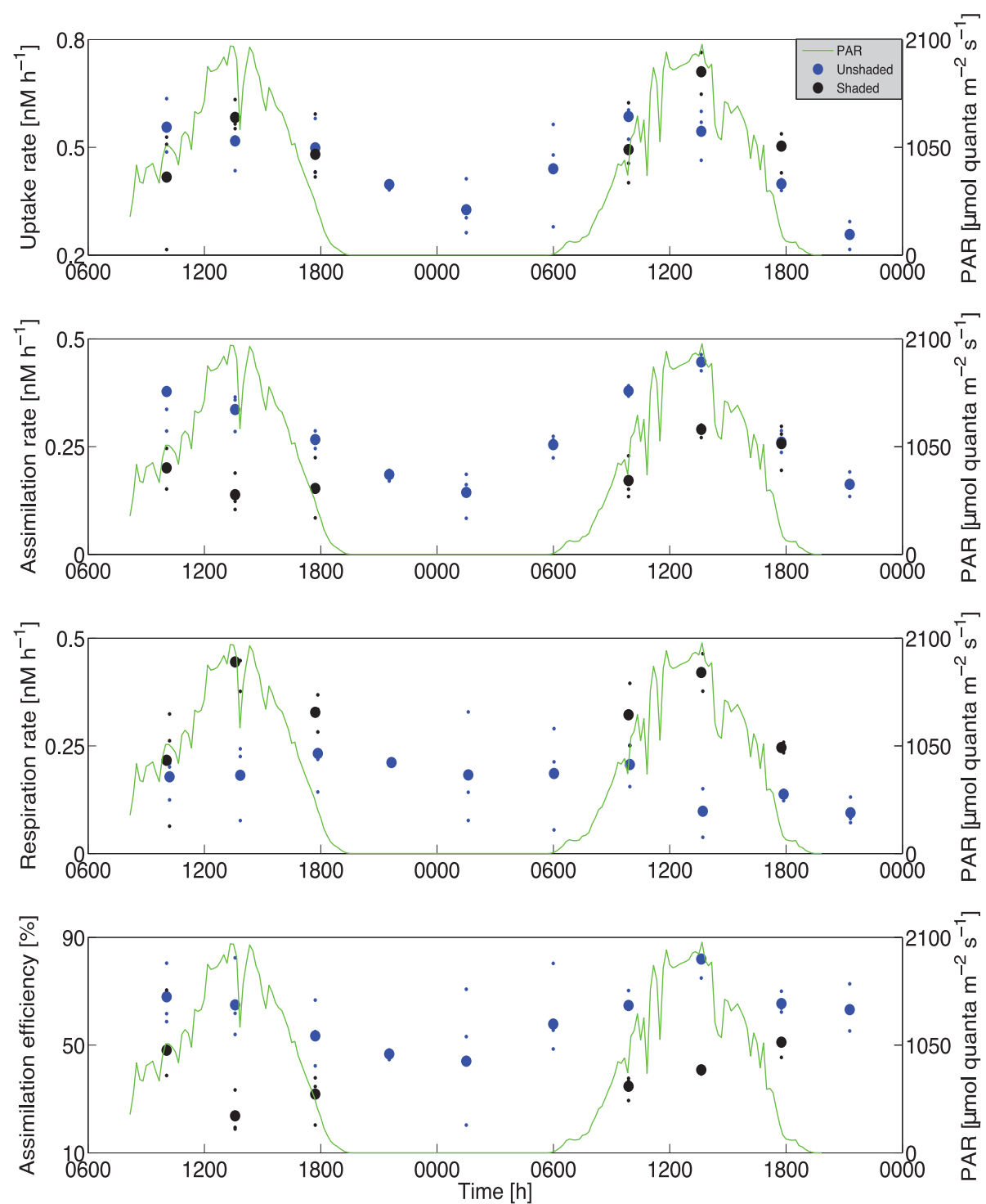

FIGURE 2 | Time-series experiment. Glycolate uptake (Top), assimilation (Second), respiration (Third), and specific assimilation efficiency (Bottom) for shaded and unshaded incubations over the course of the diel time-series experiment. Mean (large symbols) and individual data points (small symbols) are shown for clarity. Photosynthetically active radiation (PAR) data are overlaid (green line) in each panel and nighttime is indicated by shaded areas. Data points are aligned to the midpoint of each incubation. 
hours, and unshaded samples were similar over the entire daylength $(p=0.71)$. The discrepancy between daytime lightdependent responses in glycolate assimilation and respiration rates resulted in glycolate-specific growth efficiencies ranging from $24 \pm 6 \%$ in shaded daytime samples to $82 \pm 8 \%$ in unshaded daytime samples $(p<0.001)$. Even if the glycolate taken up was quantitatively respired, the maximum potential contribution of phytoplankton uptake of respired ${ }^{14} \mathrm{CO}_{2}$ calculated from isotope dilution into the very large dissolved inorganic pool of seawater (approximately 0.006 DPM) would be negligible.

\section{Glycolate Assimilation Depth Profile Experiment}

Assimilation rates decreased exponentially with depth (Figure 3), and were more closely correlated with PAR (Model II geometric mean least-squares fit; $r=0.997)$ than with PP $(r=0.88)$, GOP $(r=0.90)$, or MCR $(r=0.51)$. Importantly, within the mixed layer (36 $\mathrm{m}$; defined as the $0.125 \mathrm{~kg} \mathrm{~m}^{-3}$ offset from $0 \mathrm{~m}$ ), PP and GOP were uniform, indicating a decoupling of glycolate cycling from PP. In consideration of the differences in incubation lengths between in situ and on-deck incubations, assimilation rates at $25 \mathrm{~m}$ on the array were similar to average diel time-series assimilation rates $(p=0.71)$.

\section{Photoheterotrophic Energy Potential and Glycolate Respiration}

Energy transduction, such as the pmf generated by PR or BChla-complex, should increase the adenylate energy charge and thus increase the anabolic yield. Similarly, a quantitative substitution of the energy derived from dark glycolate respiration should be derived from light. Since numerous pathways for the assimilation of glycolate are possible, and the composition of each consumer may differ considerably, the free energy of glycolate anabolism cannot be estimated reliably. Instead, we introduce a quantity derived from the enthalpy generated by the respiration of glycolate in shaded and unshaded incubations during the daytime. This quantity, glycolate-specific energy transduction, reflects the maximum chemical potential energy derived from light-dependent processes. Glycolatespecific energy transduction was linearly correlated with PAR integrated over each daytime incubation $(r=0.97 ; p<0.001$; Figure 4). Accordingly, over the range of irradiances observed, the relationship between these two energy quantities (light and chemical energy) did not saturate.

\section{DISCUSSION}

Glycolate, a low molecular weight (76 Da) hydroxy acid, may constitute an important flux of both carbon and energy within the marine microbial community metabolism. Dark glycolate uptake kinetics indicated an upper bound ambient concentration of $30 \pm 6 \mathrm{nM}$, based on turnover time as a function of substrate added (Dietz et al., 1977). This estimate, though an upper bound (Laws, 1983), is roughly half the nighttime concentration measured by HPLC at an oligotrophic site (60-70 ng Chl a L ${ }^{-1}$ ) in the tropical eastern North Atlantic
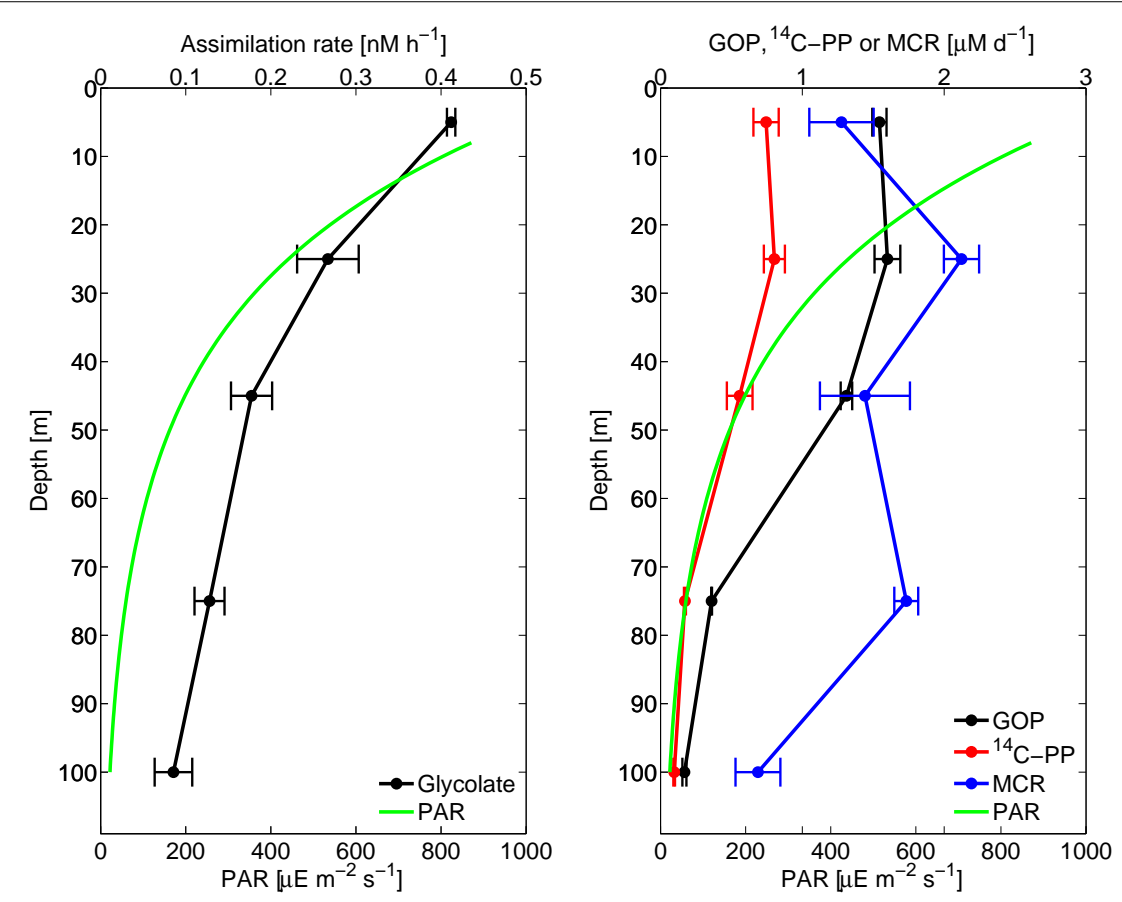

FIGURE 3 | Array profile. Depth profiles of glycolate assimilation rates (Left) and productivity [primary production (PP), gross oxygen production (GOP)] and microbial community respiration (MCR) (Right). Carbon units correspond to PP and oxygen units correspond to GOP and MCR. The accompanying PAR profile is shown in both panels. Error bars represent one standard deviation of the mean rates of three replicates at each depth. 

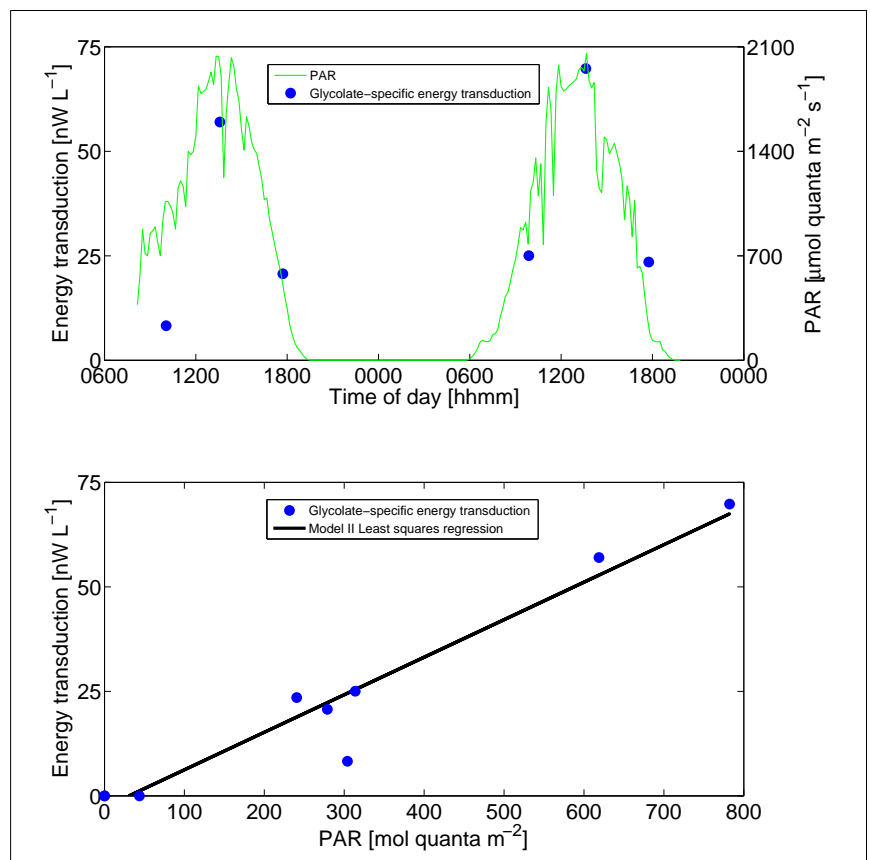

FIGURE 4 | Energy transduction. Calculated glycolate-specific energy transduction (see section "Materials and Methods" for description) and instantaneous PAR irradiance over the diel time-series experiment (Top) and as a function of incubation time-integrated PAR (Bottom). Model II geometric mean least-squares regression line is shown.

(66 nM; Leboulanger et al., 1997), and is well below the $K_{\mathrm{m}, \mathrm{U}}$ (195 nM). During the dark kinetics incubation, the glycolate pool turned over approximately daily $(1.1 \pm 0.1$ days $)$; however, this is likely an underestimate due to disequilibrium with respect to production (which is exclusively during daylight hours).

Time-series incubations showed a characteristic diel cycle in uptake rates in phase with the solar cycle, independent of whether the sample was exposed to light. Taken together with our understanding of a photorespiratory source of glycolate, these results indicate ambient concentration-dependent rates, rather than light-enhanced uptake by heterotrophs. Although the time-series experiment and kinetics experiment were conducted on separate expeditions with somewhat different phytoplankton community stocks and rates (Cruise 1: Chl

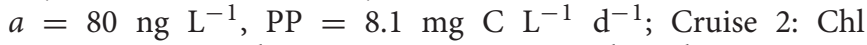
$a=137 \mathrm{ng} \mathrm{L} \mathrm{L}^{-1}, \mathrm{PP}=9.9 \mathrm{mg} \mathrm{C} \mathrm{L}^{-1} \mathrm{~d}^{-1}$ ), nighttime uptake rates (10 $\mathrm{nM}$ spike) collected during the time-series experiment closely matched the corresponding values from the kinetics curve $(p=0.81)$. With this caution, we conservatively estimate a two-fold change in ambient glycolate concentrations over the course of the diel cycle, which is consistent with estimates from the North Atlantic (2.4 \pm 1.2 -fold; Leboulanger et al., 1998). Glycolate-specific respiration rates accounted for approximately $3 \%$ of total community oxygen consumption (respiration rates), and considering the glycolate respiration quotient, $6 \%$ of total community respired $\mathrm{CO}_{2}$ (assuming a total community respiration quotient of 1.0; del Giorgio et al.,
2006; c.f., Berggren et al., 2011). On a carbon basis, glycolate production rates accounted for less than $4 \%$ of GOP in the timeseries incubations, however, this can also be interpreted as an underestimate of gross photorespiration since salvage pathways are present in some photoautotrophs. Due to methodological challenges, photorespiration rates have only been indirectly measured in the oceans (Carrillo et al., 2004), and may be an important but largely ignored flux of carbon (Karl et al., 1996).

High-light adapted 'ecotypes' (eHL) of the marine cyanobacterium Prochlorococcus, the most abundant photoautotroph at Station ALOHA, lacks glycolate oxidase or glycolate dehydrogenase, an essential step in the salvage pathway for photorespiratory glycolate regeneration of 3-phosphoglycerate. Because the precursor 2-phosphoglycolate is toxic to central carbon fixation pathways, Prochlorococcus actively excretes glycolate via an ATP-binding cassette efflux transporter. In cultures of two eHL Prochlorococcus strains, glycolate excretion was $3 \%$ of carbon fixation (Bertilsson et al., 2005), remarkably close to our upper bound estimate. It should be noted that the diazotrophic cyanobacterium Crocosphaera, which was relatively abundant during the timeseries expedition (100-700 cells $\mathrm{ml}^{-1} ; 3 \%$ of PP; calculated from Wilson et al., 2017), does have a complete photorespiratory salvage pathway. Therefore we cannot eliminate the possibility that Crocosphaera could take up glycolate. Notwithstanding, Prochlorococcus was the dominant primary producer during the time-series expedition, and was likely the major glycolate producer. Interestingly, a major consumer of glycolate is likely the numerically dominant heterotroph at Station ALOHA, SAR11, a small alphaproteobacterium with an absolute growth requirement for pyruvate and either glycolate or one of several photorespiratory salvage pathway intermediate metabolites. SAR11 has both a glycolate transporter and glycolate oxidase which yields glyoxylate and hydrogen peroxide. In addition to the apparent co-evolution of these two dominant oligotrophs (Braakman et al., 2017), SAR11 and much of the heterotrophic microbial community at Station ALOHA (Rusch et al., 2007), have genes for proteorhodopsin-based phototrophy, prompting our investigation into the light-dependent metabolism of glycolate. With a respiration quotient $\left(\mathrm{mol} \mathrm{CO}_{2}: \mathrm{mol} \mathrm{O}_{2}\right)$ of 2, a carbon redox number of 3 , and a standard carbon molar enthalpy of combustion $\left(\Delta \mathrm{H}^{\circ}{ }_{c}\right)$ of $340 \mathrm{KJ}[\mathrm{C}-\mathrm{mol}]^{-1}$, glycolate is a relatively poor energy substrate. Accordingly, heterotrophic growth on carboxylic and hydroxy acids like acetate and fatty acids typically requires the operation of the glyoxylate shunt (Kornberg, 1966), a bypass of two $\mathrm{CO}_{2}$ evolving steps of the oxidative tricarboxylic acid pathway by way of isocitrate lyase and malate synthase which allows the net accumulation of carbon through acetyl-CoA. However, at least one alternative pathway utilizing glyoxylate is present in SAR11 and many other heterotrophs, consisting of a heterotrophic analog of the photorespiratory salvage pathway which can supply precursors for gluconeogenesis (by way of 3-phosphoglycerate) or a number of amino acid synthesis pathways (by way of L-glycine). These anabolic pathways cannot be sustained without a supplemental energy source, since 
the $\mathrm{ATP} / \mathrm{NAD}(\mathrm{P}) \mathrm{H}$ ratio and yield of the glyoxylate shunt using glycolate as a substrate does not satisfy the demands of e.g., protein synthesis (calculation based on iAF1260, a metabolic model of Escherichia coli K-12 MG1655; Feist et al., 2007).

The central finding of this study, that exposure to light enhances the glycolate-specific assimilation efficiency, points to the possibility that the pmf generated by PR or by the BChlacomplex yields sufficient energy to divert glycolate flux from the mostly catabolic glyoxylate shunt to the mostly anabolic pathways. We cannot eliminate the possibility that another lightdependent process which is decoupled from PP and community respiration could reproduce our observations. However, the strong correspondence between light and glycolate-specific assimilation efficiency, independent of concentration, supports the notion that photoheterotrophy supplements cellular energy demands for growth on oxidized substrates. Furthermore, considering the $\Delta \mathrm{H}^{\circ}{ }_{c}$ and the maximum chemical potential energy yield of glycolate respiration, the resulting energy yield was closely correlated with PAR irradiance integrated over each incubation, rather than $\mathrm{PP}$ or community respiration. Unfortunately, it is not possible to 'scale' glycolate-specific phototrophic energy yields to total photoheterotrophy, since the composition of the myriad additional growth substrates and their respective uptake rates and light-dependent growth efficiencies is not known. We suggest that light-enhanced biomass yields may play an important role in the co-evolution of Prochlorococcus and SAR11 (Braakman et al., 2017), a metabolic coupling supported by the exchange of low-yield, thermodynamically optimal substrates (glycolate and pyruvate;

\section{REFERENCES}

Alonso-Saez, L., Gasol, J. M., Lefort, T., Hofer, J., and Sommaruga, R. (2006). Effect of natural sunlight on bacterial activity and differential sensitivity of natural bacterioplankton groups in northwestern Mediterranean coastal waters. Appl. Environ. Microbiol. 72, 5806-5813. doi: 10.1128/AEM.00597-06

Azam, F., Fenchel, T., Field, J. G., and Gray, J. S. (1983). The ecological role of water-column microbes in the sea. Mar. Ecol. Prog. Ser. 10, 257-263. doi: 10.3354/meps010257

Béjà, O., Aravind, L., Koonin, E. V., Suzuki, M. T., Hadd, A., Nguyen, L. P., et al. (2000). Bacterial rhodopsin: evidence for a new type of phototrophy in the sea. Science 289, 1902-1906. doi: 10.1126/science.289.5486.1902

Berggren, M., Lapierre, J. F., and del Giorgio, P. A. (2011). Magnitude and regulation of bacterioplankton respiratory quotient across freshwaters environmental gradients. ISME J. 6, 984-993. doi: 10.1038/ismej. 2011.157

Bertilsson, S., Berglund, O., Pullin, M., and Chisholm, S. W. (2005). Release of dissolved organic matter by Prochlorococcus. Vie Milieu 55, 225-232.

Bjørnsen, P. K. (1988). Phytoplankton exudation of organic matter: why do healthy cells do it? Limnol. Oceanogr. 33, 151-154. doi: 10.4319/lo.1988.33. 1.0151

Braakman, R., Follows, M. J., and Chisholm, S. W. (2017). Metabolic evolution and the self-organization of ecosystems. Proc. Natl. Acad. Sci. U.S.A. 114, E3091-E3100. doi: 10.1073/pnas.1619573114

Carrillo, C. J., Smith, R. C., and Karl, D. M. (2004). Processes regulating oxygen and carbon dioxide in surface waters west of the Antarctic Peninsula. Mar. Chem. 84, 161-179. doi: 10.1016/j.marchem.2003.07.004

Casey, J., Mardinoglu, A., Nielsen, J., and Karl, D. M. (2016). Adaptive evolution of phosphorus metabolism in Prochlorococcus. mSystems 1:e00065-16. doi: 10.1128/mSystems.00065-16 thermodynamic efficiency $=20-24 \%$; Westerhoff et al., 1983).

\section{AUTHOR CONTRIBUTIONS}

JRC, SF, and DMK planned the experiments, JRC and SF collected and processed the samples and analyzed the data. All authors contributed to the manuscript preparation and editing.

\section{FUNDING}

This work was supported by the National Science Foundation (OCE-1260164 and EF-0424599 awarded to DMK, Graduate Research Fellowship awarded to JRC), the Gordon and Betty Moore Foundation (grant \#3794 awarded to DMK), the Simons Foundation (SCOPE Award ID 329108 awarded to DMK and Edward DeLong), and the Balzan Foundation (awarded to DMK).

\section{ACKNOWLEDGMENTS}

We would like to thank the captain and crew of the $\mathrm{R} / \mathrm{V}$ Kilo Moana and chief scientist S. Wilson for their essential support during the "HOE" field campaign. We are grateful to the reviewers and to R. Bidigare, M. Church, P. Falkowski, T. Hemscheidt, and C. Nelson for their comments and helpful discussion.

Casey, J. R., Falkowski, P. G., and Karl, D. M. (2015). Substrate selection for heterotrophic bacterial growth in the sea. Mar. Chem. 177, 349-356. doi: 10.1016/j.marchem.2015.06.032

Chan, W. Y., Mosca, P., and Rennert, O. M. (1981). Lithium nephrotoxicity: a review. Ann. Clin. Lab. Sci. 11, 343-349.

Church, M. J., Ducklow, H. W., and Karl, D. M. (2004). Light dependence of $\left[{ }^{3} \mathrm{H}\right]$ Leucine incorporation in the oligotrophic North Pacific Ocean. Appl. Environ. Microbiol. 70, 4079-4087. doi: 10.1128/AEM.70.7.4079-4087.2004

Church, M. J., Ducklow, H. W., Letelier, R. M., and Karl, D. M. (2006). Temporal and vertical dynamics in picoplankton photoheterotrophic production in the subtropical North Pacific Ocean. Aquat. Microb. Ecol. 45, 41-53. doi: 10.3354/ ame045041

Cottrell, M. T., Michelou, V. K., Nemcek, N., DiTullio, G., and Kirchman, D. L. (2008). Carbon cycling by microbes influenced by light in the Northeast Atlantic Ocean. Aquat. Microb. Ecol. 50, 239-250. doi: 10.3354/ame01173

del Giorgio, P. A., Pace, M., and Fischer, D. (2006). Relationship of bacterial growth efficiency to spatial variation in bacterial activity in the Hudson River. Aquat. Microb. Ecol. 45, 55-67. doi: 10.3354/ame045055

Dietz, A. S., Albright, L. J., and Tuominen, T. (1977). Alternative model and approach for determining microbial heterotrophic activities in aquatic systems. Appl. Environ. Microbiol. 33, 817-823.

Dimroth, P. (1990). Mechanisms of sodium transport in bacteria. Philos. Trans. R. Soc. Lond. B Biol. Sci. 326, 465-477. doi: 10.1098/rstb.1990.0025

Feist, A. M., Henry, C. S., Reed, J. L., Krummenacker, M., Joyce, A. R., Karp, P. D., et al. (2007). A genome-scale metabolic reconstruction for Escherichia coli K-12 MG1655 that accounts for 1260 ORFs and thermodynamic information. Mol. Syst. Biol. 3, 121. doi: 10.1038/msb4100155

Feng, S., Powell, S. M., Wilson, R., and Bowman, J. P. (2013). Light-stimulated growth of proteorhodopsin-bearing sea-ice psychrophile Psychroflexus torquis is salinity dependent. ISME J. 7, 2206-2213. doi: 10.1038/ismej.2013.97 
Ferrón, S., del Valle, D. A., Björkman, K. M., Quay, P. D., Church, M. J., and Karl, D. M. (2016). Application of membrane inlet mass spectrometry to measure aquatic gross primary production by the ${ }^{18} \mathrm{O}$ in vitro method. Limnol. Oceanogr. Methods 14, 610-622. doi: 10.1002/lom3.10116

Fogg, G. E. (1983). The ecological significance of extracellular products of phytoplankton photosynthesis. Bot. Mar. 26, 3-14. doi: 10.1515/botm.1983. 26.1.3

Frigaard, N.-U., Martinez, A., Mincer, T. J., and Delong, E. F. (2006). Proteorhodopsin lateral gene transfer between marine planktonic Bacteria and Archaea. Nature 439, 847-850. doi: 10.1038/nature 04435

Fuhrman, J. A., and Ferguson, R. L. (1986). Nanomolar concentrations and rapid turnover of dissolved free amino-acids in seawater-agreement between chemical and microbiological measurements. Mar. Ecol. Prog. Ser. 33, 237-242. doi: $10.3354 /$ meps033237

Gómez-Consarnau, L., Akram, N., Lindell, K., Pedersen, A., Neutze, R., Milton, D. L., et al. (2010). Proteorhodopsin phototrophy promotes survival of marine bacteria during starvation. PLOS Biol. 8:e1000358. doi: 10.1371/journal.pbio. 1000358

Gómez-Consarnau, L., González, J. M., Coll-Lladó, M., Gourdon, P., Pascher, T., Neutze, R., et al. (2007). Light stimulates growth of proteorhodopsincontaining marine flavobacteria. Nature 445, 210-213. doi: 10.1038/nature 05381

Gómez-Pereira, P. R., Hartmann, M., Grob, C., Tarran, G. A., Martin, A. P., Fuchs, B. M., et al. (2012). Comparable light stimulation of organic nutrient uptake by SAR11 and Prochlorococcus in the North Atlantic subtropical gyre. ISME J. 7, 603-614. doi: 10.1038/ismej.2012.126

Inoue, K., Ono, H., Abe-Yoshizumi, R., and Yoshizawa, S. (2013). A light-driven sodium ion pump in marine bacteria. Nat. Commun. 4:1678. doi: 10.1038/ ncomms 2689

Johnston, W., Cooney, M., Schorlemmer, A., Pohl, S., Karl, D. M., and Bidigare, R. (2005). Carbon mass balance methodology to characterize the growth of pigmented marine bacteria under conditions of light cycling. Bioprocess Biosyst. Eng. 27, 163-174. doi: 10.1007/s00449-004-0395-8

Kana, T. M., Darkangelo, C., Duane Hunt, M., Oldham, J. B., Bennett, G. E., and Cornwell, J. C. (1994). Membrane inlet mass spectrometer for rapid highprecision determination of $\mathrm{N}_{2}, \mathrm{O}_{2}$, and $\mathrm{Ar}$ in environmental water samples. Anal. Chem. 66, 4166-4170. doi: 10.1021/ac00095a009

Karl, D. M. (2014). Solar energy capture and transformation in the sea. Elem. Sci. Anth. 2:21. doi: 10.12952/journal.elementa.000021

Karl, D. M., Christian, J. R., Dore, J. E., and Letelier, R. M. (1996). "Microbiological oceanography in the region west of the Antarctic Peninsula: microbial dynamics, nitrogen cycle, and carbon flux," in Foundations for Ecological Research West of the Antarctic Peninsula. Antarctic Research Series, Vol. 70, eds R. M. Ross, E. E. Hofmann, and L. B. Quetin (Washington, DC: American Geophysical Union), 303-332.

Karl, D. M., and Dore, J. E. (2001). "Microbial ecology at sea: sampling, subsampling and incubation considerations," in Methods in Microbiology, Vol. 30, ed. J. H. Paul (Cambridge, MA: Academic Press).

Kimura, H., Young, C. R., Martinez, A., and Delong, E. F. (2011). Lightinduced transcriptional responses associated with proteorhodopsin-enhanced growth in a marine flavobacterium. ISME J. 5, 1641-1651. doi: 10.1038/ismej. 2011.36

Koblížek, M., Mlèoušková, J., Kolber, Z., and Kopecký, J. (2010). On the photosynthetic properties of marine bacterium COL2P belonging to Roseobacter clade. Arch. Microbiol. 192, 41-49. doi: 10.1007/s00203-0090529-0

Kornberg, H. L. (1966). The role and control of the glyoxylate cycle in Escherichia coli. Biochem. J. 99, 1-11. doi: 10.1042/bj0990001

Kwon, S. K., Kim, B. K., Song, J. Y., Kwak, M. J., Lee, C. H., Yoon, J. H., et al. (2013). Genomic makeup of the marine flavobacterium Nonlabens (Donghaeana) dokdonensis and identification of a novel class of rhodopsins. Genome Biol. Evol. 5, 187-199. doi: 10.1093/gbe/evs134

Laws, E. A. (1983). Plots of turnover times versus added substrate concentrations provide only upper bounds to in situ substrate concentrations. J. Theor. Biol. 101, 147-150. doi: 10.1016/0022-5193(83)90278-3

Laws, E. A. (1997). Mathematical Methods for Oceanographers. New York, NY: John Wiley and Sons.
Leboulanger, C., Oriol, L., Jupin, H., and Desolas-Gros, C. (1997). Diel variability of glycolate in the eastern tropical Atlantic Ocean. Deep Sea Res. I 44, 2131-2139. doi: 10.1016/S0967-0637(97)00090-3

Leboulanger, C., Serve, L., Comellas, L., and Jupin, H. (1998). Determination of glycolic acid released from marine phytoplankton by post-derivatization gas chromatography-mass spectrometry. Phytochem. Anal. 9, 5-9. doi: 10.1002/(SICI)1099-1565(199801/02)9:1<5::AID-PCA378>3.0.CO;2-\#

Mague, T. H., Friberg, E., Hughes, D. J., and Morris, I. (1980). Extracellular release of carbon by marine phytoplankton: a physiological approach. Limnol. Oceanogr. 25, 262-279. doi: 10.4319/lo.1980.25.2.0262

Mary, I., Tarran, G. A., Warwick, P. E., Terry, M. J., Scanlan, D. J., Burkill, P. H., et al. (2008). Light enhanced amino acid uptake by dominant bacterioplankton groups in surface waters of the Atlantic Ocean. FEMS Microbiol. Ecol. 63, 36-45. doi: 10.1111/j.1574-6941.2007.00414.x

McCarren, J., and DeLong, E. F. (2007). Proteorhodopsin photosystem gene clusters exhibit co-evolutionary trends and shared ancestry among diverse marine microbial phyla. Environ. Microbiol. 9, 846-858. doi: 10.1111/j.14622920.2006.01203.x

Michelou, V. K., Cottrell, M. T., and Kirchman, D. L. (2007). Light-stimulated bacterial production and amino acid assimilation by cyanobacteria and other microbes in the North Atlantic Ocean. Appl. Environ. Microbiol. 73, 5539-5546. doi: 10.1128/AEM.00212-07

Mopper, K., Stubbins, A., Ritchie, J. D., Bialk, H. M., and Hatcher, P. G. (2007). Advanced instrumental approaches for characterization of marine dissolved organic matter: extraction techniques, mass spectrometry, and nuclear magnetic resonance spectroscopy. Chem. Rev. 107, 419-442. doi: $10.1021 / \mathrm{cr} 050359 \mathrm{~b}$

Nalewajko, C., Chowdhuri, N., and Fogg, G. E. (1963). "Excretion of glycolic acid and the growth of a planktonic Chlorella," in Microalgae and Photosynthetic Bacteria, ed. The Japanese Society of Plant Physiologists (Tokyo: University of Tokyo Press), 171-183.

Palovaara, J., Akram, N., Baltar, F., Bunse, C., Forsberg, J., Pedrós-Alió, C., et al. (2014). Stimulation of growth by proteorhodopsin phototrophy involves regulation of central metabolic pathways in marine planktonic bacteria. Proc. Natl. Acad. Sci. U.S.A. 111, E3650-E3658. doi: 10.1073/pnas.1402617111

Rusch, D. B., Halpern, A. L., Sutton, G., Heidelberg, K. B., Williamson, S., Yooseph, S., et al. (2007). The Sorcerer II global ocean sampling expedition: northwest Atlantic through eastern tropical Pacific. PLOS Biol. 5:e77. doi: 10.1371/journal.pbio.0050077

Sharp, J. H. (1977). Excretion of organic matter by marine phytoplankton: do healthy cells do it? Limnol. Oceanogr. 22, 381-399. doi: 10.4319/lo.1977.22.3. 0381

Shiba, T., Simidu, U., and Taga, N. (1979). Distribution of aerobic bacteria which contain bacteriochlorophyll a. Appl. Environ. Microbiol. 38, 43-45.

Steindler, L., Schwalbach, M. S., Smith, D. P., and Chan, F. (2011). Energy starved Candidatus Pelagibacter ubique substitutes light-mediated ATP production for endogenous carbon respiration. PLOS ONE 6:e19725. doi: 10.1371/journal. pone. 0019725

Tolbert, N. E., and Zill, L. P. (1957). "Excretion of glycolic acid by Chlorella during photosynthesis," in Research in Photosynthesis, ed. H. Gaffron (New York, NY: Interscience Publishers), 228-231.

von Stockar, U., Maskow, T., Liu, J., and Marison, I. W. (2006). Thermodynamics of microbial growth and metabolism: an analysis of the current situation. J. Biotechnol. 121, 517-533. doi: 10.1016/j.jbiotec.2005.08.012

Westerhoff, H. V., Hellingwerf, K. J., and Van Dam, K. (1983). Thermodynamic efficiency of microbial growth is low but optimal for maximal growth rate. Proc. Natl. Acad. Sci. U.S.A. 80, 305-309. doi: 10.1073/pnas.80. 1.305

Wilson, S. T., Aylward, F. O., Ribalet, F., Barone, B., Casey, J. R., Connell, P. E., et al. (2017). Coordinated regulation of growth, activity and transcription in natural populations of the unicellular nitrogen-fixing cyanobacterium Crocosphaera. Nat. Microbiol. 2:17118. doi: 10.1038/nmicrobiol.2017.118

Wright, R. T., and Shah, N. M. (1977). The trophic role of glycolic acid in coastal seawater. I. Heterotrophic metabolism in seawater and bacterial cultures. Mar. Biol. 33, 175-183. doi: 10.1007/BF00390723

Yoshizawa, S., Kumagai, Y., Kim, H., Ogura, Y., Hayashi, T., Iwasaki, W., et al. (2014). Functional characterization of flavobacteria rhodopsins 
reveals a unique class of light-driven chloride pump in bacteria. Proc. Natl. Acad. Sci. U.S.A. 111, 6732-6737. doi: 10.1073/pnas.140305 1111

Zigah, P. K., McNichol, L., Xu, C., Johnson, C. S., Karl, D. M., and Repeta, D. J. (2017). Allochthonous sources and dynamic cycling of oceanic dissolved organic carbon cycle revealed by carbon isotopes. Geophys. Res. Lett. 44, 2407-2415.

Ziolkowski, L. A., and Druffel, E. R. M. (2010). Aged black carbon identified in marine dissolved organic carbon. Geophys. Res. Lett. 37:L16601. doi: 10.1029/ 2010GL043963
Conflict of Interest Statement: The authors declare that the research was conducted in the absence of any commercial or financial relationships that could be construed as a potential conflict of interest.

Copyright (c) 2017 Casey, Ferrón and Karl. This is an open-access article distributed under the terms of the Creative Commons Attribution License (CC BY). The use, distribution or reproduction in other forums is permitted, provided the original author(s) or licensor are credited and that the original publication in this journal is cited, in accordance with accepted academic practice. No use, distribution or reproduction is permitted which does not comply with these terms. 